\title{
O gênero como órgão de memória em filmes de ficção-científica
}

\author{
Gender as a body memory in science-fiction films
}

\author{
Carmen Irene Correia Oliveira ${ }^{1}$
}

\begin{abstract}
Trabalha o conceito de memória de gênero (Bakhtin), a partir de remakes de ficção-científica. Toma o gênero como uma força dinâmica que trabalha no sentido da permanência e da mudança, articulando os elementos que determinam a intertextualidade. Na corrente de uma longa tradição, uma obra traz as características marcantes de um gênero que funciona como um "órgão de memória" em um sentido relativamente autônomo. Afirma que, no contexto dos filmes analisados, os elementos que se propagam dentro do gênero sofreram algumas variações nas refilmagens, em função do contexto sócio-histórico, ao passo que a permanência é marcada pelos temas recorrentes.
\end{abstract}

Palavras-chaves: Remakes. Ficção-científica. Memória de gênero. Filmes. Mikhail Bakhtin.

\section{Resumo}

This concept of working memory genre (Bakhtin), from remakes science-fiction. Takes gender as a dynamic force that works towards permanence and change, articulating the elements that determine intertextuality. In current a long tradition, a work brings the outstanding characteristics of a genre that works as a "body memory" in a relatively autonomous way. States that, in the context of the films analyzed, the elements that propagate within the genre underwent some changes in reshoots, depending on the socio-historical context, while the stay is marked by recurring themes.

Keywords: Remakes. Science fiction. Memory of genre. Films. Mikhail Bakhtin.

\section{Introdução}

Nas palavras de Jean Marigny (1994), a ciência, desde as Luzes até o século XX, operou um expurgo em todas as outras formas de compreensão da realidade, procurando reinar quase que majoritariamente nos quadros de referência do pensamento humano na explicação do mundo e dos eventos. O que denominamos ciência moderna, nas palavras do autor, apoia-se firmemente no raciocínio matemático rigoroso, excluindo o que não é verificável, mensurável e reprodutível em laboratório. Ao mesmo tempo, é nesse contexto

\footnotetext{
${ }^{1}$ Doutora em Ciência da Informação pela Universidade Federal Fluminense, em convênio com o IBICT. Professora da Universidade Federal do Estado do Rio de Janeiro. Departamento de Filosofia e Ciências Sociais. Docente Permanente do Programa de PósGraduação em Educação e do Programa de Pós-Graduação em Memória Social. E-mail: capmont@hotmail.com
} 
que a literatura da imaginação, o fantástico e, posteriormente, a ficção-científica (doravante scifi) insistem em apontar a ambiguidade da relação entre ciência e esse outro: o irracional, o fantástico, o mito.

As expressões ficcionais da ciência são narrativas que demandam, para sua discussão, uma incursão em relações com o mito e incluem o imaginário como elemento transversal. Nesse sentido, o que nos interessa são as representações que alimentam a constituição de um espaço no qual a ciência figura como fundamento principal de visões de mundo e expectativas humanas, ou seja, as formas de representação da ciência que tomam outro tempo e espaço como base, constituindo o que a literatura denomina imaginário tecnomaquínico.

Este artigo tem como objetivo apresentar resultados de uma pesquisa que toma como objeto remakes de sci-fi e, através de uma análise que considera elementos de permanência e mudança de uma produção a outra, discute o potencial do gênero como órgão de memória na delimitação da $s c i-f$. Trabalhamos com uma delineação construída por Bakhtin, a partir dos seus estudos sobre a obra de Dostoiévsky, quando ele especula sobre o gênero como um órgão de memória. O conceito de memória de gênero se tornou, em nosso trabalho, tanto uma categoria teórica como uma categoria analítica.

Não cabe, no espaço do presente artigo, um histórico do nascimento da sci-fi, desde que algumas histórias foram identificadas, por alguns autores, como já apontando para a criação de universos diferenciados. Para tal, uma leitura de Stableford (2003) é recomendada. No que diz respeito à discussão sobre o delineamento da $s c i$ fi como um gênero, a literatura fornece trabalhos instigantes, como os de Darko Suvin (1976, 1979), que propõem o estranhamento cognitivo como um elemento importante para compreender a sci-fi, sendo que sua concepção de novum é de interesse em nossas considerações.

O nosso posicionamento não é de contraposição nem de alinhamento. Procuramos, a partir de uma noção já presente nos estudos de gênero, realizar uma análise que pudesse consubstanciar uma discussão sobre como as narrativas de $s c i-f i$ podem ser percebidas em contexto que toma o gênero como órgão de memória. Em nossas análises, percebemos que dentro do gênero de sci-fi, tendo em vista a relação em destaque (permanência e mudança), as transformações se vinculam ao contexto de produção, e as permanências, ao trabalho organizador do gênero. Nesse cenário, as narrativas são constituintes de uma dinâmica que engloba a manutenção/transformação de elementos de uma memória mítica da ciência ficcionalizada.

O nosso corpus é constituído por famílias de filmes, nome dado a um conjunto que engloba a primeira versão de um filme e suas demais versões. São cinco famílias de filmes e doze produções analisadas, que estão detalhadas na parte das análises.

\section{O Gênero como Órgão de Memória}

O conceito de gênero, no cinema, funcionou para estabilizar uma indústria inicialmente instável $^{2}$. Uma produção vasta e variada, com custos altos e sem nenhuma previsão de sucesso: esse era o contexto que o sistema de gênero e o star system vieram ordenar. Nesse sentido, um filme que pertencesse a um determinado gênero seria produzido, seguindo um conjunto fixo de caracteres e tipos, situações, costumes, temáticas, convenções e uma iconografia visual que seriam compartilhados por outros filmes daquele gênero em particular.

\footnotetext{
${ }^{2}$ Estamos nos referindo ao período que a literatura sobre cinema abarca como sendo o fim do século XIX até os anos de 1920.
} 
Com isso, o espectador, ao assistir a um filme, esperava identificar elementos que eram similares aos outros filmes (do mesmo gênero) aos quais já havia assistido. Essa identificação garantia a adesão do público e funcionava como um dos elementos de controle da produção. Para Belton (1994), o estudo do sistema de gênero é indispensável para compreender o cinema hollywoodiano clássico e, considerando nosso campo, tal perspectiva tornouse necessária. Podemos perceber que o filme de gênero trabalha com uma combinação entre o novo e o familiar; o espectador reconhece as convenções do gênero e tal reconhecimento já é uma fruição estética. No entanto, a novidade não deve chegar ao nível de uma originalidade total, sob o risco de sacrificar a comunicação. Assim, podemos perceber a importância do gênero naquilo que ele organiza e naquilo que ele permite como transgressão. Tal perspectiva é aquela que encontramos nos estudos de Mikhail Bakhtin, como veremos mais adiante.

O potencial dessa noção, no trabalho com filmes, já foi indicada por Robert Burgoyne (2002), ao analisar produções que recolocam questões de memória e identidade da história e cultura norte-americana, considerando os discursos não dominantes. Ele tomou a concepção bakhtiniana, para discutir como o cinema de Hollywood, apesar de se apresentar como indústria de entretenimento, pode ser percebido como expressão das dimensões míticas da nação. Ele trabalha com o conceito de memória de gênero de Bakhtin, por considerá-lo adequado para abordar o que ele afirma ser um dos aspectos mais notáveis de um conjunto de produções norte-americanas: o trabalho, pela retórica do gênero, do mito de guerra e conflitos nacionais para subsidiar as novas formas de coerência social ${ }^{3}$.

A noção de memória de gênero tomou forma explícita, na edição de 1963 do livro sobre a poética de Dostoiévsky. Para Bakhtin, Dostoiévsky "criou uma revolução nos gêneros em prosa; e porque os gêneros são formas de pensamento, segue-se que Dostoiévsky, também, criou uma revolução nos meios de pensar sobre o mundo" (MORSON; EMERSON, 1990, p. 280). Tomadas no conjunto, as obras de Dostoiévsky são marcadas pela "multiplicidade de vozes e consciências independentes e imiscíveis" e por uma "autêntica polifonia de vozes plenivalentes", ou seja, vozes carregadas de valor e em relação de igualdade com outras vozes dentro do espaço narrativo (BAKHTIN, 2005 , p. 4). Nesse contexto, é que se estruturam as noções de gênero e de dialogia, como bases da relação da nossa palavra com a do outro. Diante da linguagem nessa perspectiva dinâmica, o sujeito conta com um sistema organizador: o gênero do discurso. As palavras teriam assim uma vida dupla: "Elas vivem no curso inesperado e imprevisível do desenvolvimento das trocas verbais, mas, ao mesmo tempo, pertencem a funcionamentos sociais previsíveis e esperados, em que o sujeito pode se apoiar (CLOT, 2006, p. 223).

Assim, o gênero tem uma ligação intensa com um evento no mundo social (CLOT, 2006). Ou, como afirmam Morson e Emerson (1990), o gênero reflete as mudanças sociais e, de forma retroativa, um novo gênero, quando emerge, procura "ensinar" a se ver os aspectos da realidade sob uma nova forma.

O caminho de Bakhtin, na compreensão da obra de Dostoiévski, inclui o delineamento dos contatos que tal obra teve com outros gêneros, mais precisamente, a vivência e renovação da tradição de outros gêneros na ficção do escritor russo. Nas palavras de Bakhtin (2005, p. 161) “[...], nos interessa a influência de autores individuais, obras individuais, temas, imagens e ideias individuais, pois estamos interessados precisamente na influência $d a$

\footnotetext{
${ }^{3}$ Burgoyne analisa filmes como JFK, a pergunta que não quer calar; Coração de trovão e Tempo de Glória, dentre outros, para evidenciar uma perspectiva revisionista da história americana e situá-la na condição de elemento para a memória social.
} 
própria tradição do gênero, transmitida através dos escritores [...]."

Bakhtin (2005, p. 159) afirma que o escritor não precisa conhecer por completo uma tradição, pois o gênero tem uma lógica orgânica (não abstrata) que pode "ser entendida e criativamente dominada a partir de poucos protótipos ou até fragmentos". Cada nova obra que retoma a tradição de um gênero contribui com a renovação de sua linguagem. Esse posicionamento é fundamental para compreender o enriquecimento operado por Dostoiévski, em seu método polifônico, a partir de uma tradição que remontava aos gregos: a sátira menipeia. $\mathrm{Ou}$ seja, Dostoiévski não precisou lembrar muito do passado, pois o gênero fez isso por ele: “[...] Em termos um tanto paradoxais, podemos dizer que quem conservou as particularidades da menipeia antiga não foi a memória subjetiva de Dostoiévski, mas a memória objetiva do próprio gênero com o qual ele trabalhou." (BAKHTIN, 2005, p. 121).

Na perspectiva da memória de gênero, escritores como Dostoiévski e Shakespeare (exemplos citados por Bakhtin) têm uma relação especial com a tradição, pois, muito mais que outros, eles perceberam a rica força das fontes do passado que são carregadas pelo gênero. $\mathrm{O}$ gênero, na argumentação do teórico russo, conserva os elementos do passado, mas graças a uma permanente renovação. Ele "[...] sempre é e não é o mesmo, sempre é novo e velho ao mesmo tempo [...] O gênero vive do presente, mas sempre recorda o seu passado, o seu começo. É o representante da memória criativa no processo de desenvolvimento literário. É precisamente por isto que tem a capacidade de assegurar a unidade e a continuidade desse desenvolvimento." (BAKHTIN, 2005, p. 106).

$\mathrm{O}$ modo de funcionamento do gênero em Bakhtin, assim como a possibilidade de pensar em um conceito de gênero como um sistema organizador e não cerceador da criatividade, nos levou a adotá-lo como conceito e como categoria operatória. Principalmente, quando, na dialética da permanência $\mathrm{X}$ mudança, procuramos identificar elementos formadores do gênero de sci-fi. Nesse sentido, os remakes propiciam um grupo adequado de produções onde o que permanece (como elemento temático de produção) e o que se modifica (em função do contexto de produção) são identificáveis, por meio de um cotejamento entre a primeira versão e as demais. Cabe, nesse sentido, apresentar, de modo mais sistematizado, o remake como processo cinematográfico.

\section{A Problemática dos Remakes}

Mazdon (2004, p. 2) nos diz que o remake é um processo muito mais complexo do que alguns críticos querem nos fazer acreditar. Apesar de sua importância, ele não tem merecido muita atenção, por parte dos estudos teóricos: “Até pouco tempo, era perceptível que, do pouco material produzido referente ao remake, a maioria era jornalístico e em tom negativo, enquanto as monografias atingiram não mais do que momentâneos comentários". Ao abordar esse fenômeno, considerando as noções de reescritura, adaptação e tradução, a reescritura, mesmo em função de ser discutida a partir dos estudos literários, é um processo que coloca em jogo duas narrativas em um processo de aceitação ou rejeição (dos trabalhos que são reescritos). A adaptação, por seu turno, implica uma readequação, em função de linguagens e sistemas de circulação diferentes. E assim como a tradução, ela se relaciona à percepção de culturas dominantes e dominadas. "Uma cultura dominada (em outras palavras, uma cultura relativamente pequena ou pobre, ou uma no processo de formação) tenderá a traduzir bem mais do que a cultura dominante." (MAZDON, 2004, p. 2). Nesse processo, pode haver tanto a incorporação de elementos culturais do texto fonte, quanto a adequação de elementos culturais da cultura que importa no processo de tradução do texto. Em tal contexto, o remake é uma reescritura? Ao se refilmar uma produção, consolida-se seu papel de obra cuja importância no sistema cinematográfico é 
destacável? O remake, também, pode ser entendido como uma tradução, principalmente nos casos das produções estrangeiras que são refilmadas por Hollywood? Tais questões se tornam presentes na discussão de Mazdon.

Bazin talvez tenha sido um dos primeiros a discutir essa questão. Já nos anos cinquenta, ele afirma que "a lenta evolução das artes plásticas ou literárias estabeleceu-se tanto sobre a cópia quanto sobre a invenção" (BAZIN, 1952, p. 54). No caso específico dos filmes, o crítico aponta envelhecimento como um dos motores do remake: “[...] não é de se espantar que o público se desinteresse por um filme - mesmo uma obra de arte - quando seu envelhecimento torna-se perceptível" (BAZIN, 1952, p. 55). Alguns sinais de caducidade perceptíveis seriam a passagem do cinema mudo para o sonoro, do preto e branco para o colorido e os efeitos técnicos especiais. Ainda nesse caminho, temos Umberto Eco (1994), para quem a novidade constitui um critério de julgamento do valor artístico na modernidade. Em contrapartida, a repetição de um motivo já conhecido era, para as teorias modernas, do campo artesanal ou da indústria. A estética moderna teria esquecido a tradição clássica, que não era tão ávida pela inovação a todo preço, e, paulatinamente, a repetição, a obediência a esquemas pré-estabelecidos e a redundância tornaram-se elementos religados aos produtos da cultura de massa. Nessa perspectiva, a repetição é vista pela perspectiva do apelo comercial e não com um potencial provocador de uma visão de mundo nova.

Apesar da dificuldade em se definir o que é um remake, é possível enumerar uma série de situações nas quais diferentes tipos de remakes podem ser delineados. Para Serceau e Protopopof (1989), por exemplo, no lugar de tentar definir o que é “indefinível", é preferível se interrogar acerca da função sociomítica do remake, seguindo um caminho no qual o cinema é abordado como um espaço para que mitos e mitologias se consolidassem, tendo ou não uma existência anterior. Serceau e Protopopof
(1989) discutem, ainda, acerca do potencial de o remake funcionar como um "revelador" do contexto socioideológico de produção. Se todo filme, como pressupomos, possui as condições de funcionar nesse sentido, os remakes de sci-fi carregam em si a possibilidade de evidenciar, pelo processo comparativo, as diferenças que marcam as diferentes versões e, a partir delas, discutir como cada período possibilitou, ao refilmar um filme anterior, construir uma representação ficcional de ciência.

\section{A Sci-Fi: A Construção de Mundos Possíveis}

Nos idos de 1960, Isaac Asimov teve uma série de trabalhos de sua autoria traduzida para o alemão. O editor supervisionou todo trabalho, gerando boas traduções, mas introduziu o que Asimov assinalou como "notas dissonantes introduzidas a respeito dos nomes dos personagens", que continuavam em inglês. Em contato com o editor, o escritor observou que, se os nomes não representavam qualquer papel nas histórias, por que eles (as personagens) não foram transformados em alemãs, por exemplo? "Jamais - disse o editor. Se eu assim fizesse, essas histórias não pareceriam sci-fi. Aos olhos de um europeu, a sci-fi precisa ter personagens norteamericanos, para que tenham o aspecto de coisa real." (ASIMOV, 1984, p. 202). Este gênero teria, então, uma nacionalidade? O próprio Asimov não acreditava nisso, mas alguns teóricos creem que sim, principalmente se tomarmos o far western, o que não é o presente caso.

A sci-f $i$ pode ser considerada um dos tipos ou subgêneros da literatura narrativa em que, na composição do enredo e de seus personagens, da ambiência social e das circunstâncias históricas, têm papel fundamental, as questões científicas e o uso das tecnologias, em geral, mais desenvolvidas ou avançadas do que aquelas existentes na época contemporânea. Nesse sentido, essas narrativas podem: a) antecipar o desenvolvimento da tecnociência de modo utópico; b) desenhar situações antiutópicas em outras conformações 
sociais anti-humanistas, "nas quais se evidenciam as relações entre o poder político, as relações sociais e o uso das tecnologias." (CUNHA, 2003, p. 283).

Para Cardoso (2006), a ciência aliada à tecnologia não é somente um componente da $s c i-f$, ela foi um dos principais pressupostos para que ela surgisse e se mantivesse como gênero. Ele aponta três movimentos ou condições que embasam sua constituição: 1) seu nascimento, como gênero literário, supôs a fixação do romance moderno e do conto; 2) a consolidação da ciência como horizonte de plausabilidade e legitimidor de uma visão de mundo; 3 ) a mudança de percepção do tempo, tanto natural quanto social, decorrentes da revolução científica e das revoluções sociais, principalmente a Francesa, "destruindo as visões cíclicas e trazendo a convicção de que o presente difere do passado e de que o futuro, por sua vez, será diferente do presente" (CARDOSO, 2006, p. 22). No entanto, mesmo sendo a ciência uma personagem principal, parece que a $s c i-f i$ constitui uma especificidade, no cumprimento de uma função mítica, conforme ressalta o mesmo autor.

A questão da emergência e consolidação da ciência como horizonte, fato que viabilizou a $s c i$ - $f i$ como gênero, também, era o posicionamento de um dos principais nomes desse campo: Isaac Asimov. Para Asimov (1984), os acontecimentos suprarreais (presentes em outras formas de ficção) podem, no caso da $s c i-f$, ser "concebivelmente derivados do nosso próprio meio social, mediante adequadas mudanças ao nível da ciência e da tecnologia." (ASIMOV, 1984, p. 26). Essas mudanças podem representar tanto um avanço, no caso de descobertas e colonização em outros planetas, como um retrocesso, em casos de destruição nuclear. Dessa forma, uma de suas definições está baseada em tal concepção: "Ficção-científica pode ser definida como o ramo da literatura que lida com respostas humanas a mudanças ao nível da ciência e da tecnologia" (ASIMOV, 1984, p. 97).
Asimov (1984) é taxativo em afirmar que a ideia de uma sci-fi, tendo em vista o conceito de ciência que está implicado no gênero, não poderia ter surgido antes de se ter desenvolvida a noção de mudanças sociais advindas do desenvolvimento técnico-científico. Ou seja, ele relaciona estreitamente este gênero a um contexto, no qual as mudanças e avanços tecnológicos e científicos, assim como os seus efeitos sobre a sociedade, tornam-se acentuados o suficiente para serem percebidos no transcurso de uma existência. Só então, pela primeira vez, o futuro é concebido. "O importante em matéria de sci-fi, até mesmo fundamental, é aquilo que efetivamente a fez surgir, ou seja, a percepção das mudanças produzidas pela tecnologia." (ASIMOV, 1984, p. 18). Suas posições transitam em torno da ideia moderna de ciência como caldo fundamental para gestação das ficções científicas.

\section{A Sci-Fi Cinematográfica}

Após a Segunda Guerra Mundial, um novo contexto sociopolítico-ideológico parece determinar as mudanças nas representações que povoam o imaginário tecnomaquínico e a percepção de futuro do desenvolvimento científico para a humanidade.

Um evento, no dia 24 de junho de 1947, alimentou com novos elementos, aliados à paranoia norte-americana da invasão comunista, o imaginário que começa a se constituir. Kenneth Arnold, um homem de negócios norte-americano, decide dar uma volta em seu avião particular. Ao contornar o Monte Raimei no estado de Washington, ele vê aparelhos voadores em forma de disco. O mistério desses objetos começa, na imprensa, a desencadear uma série de comentários e suposições acerca de sua origem. "A opinião pública trabalhada pela imprensa começa a atribuir a esses misteriosos fenômenos uma origem bem definida" (SICILIER; LABARTE, 1958, p. 56) Começava-se a pensar que tais objetos eram construídos e enviados pelos soviéticos para observar o território americano. O 
clima de histeria, começa a se instalar, chegando, inclusive, ao Secretário de Estado de Defesa, James Forrestal, que se joga de uma janela em 11 de abril de 1949, crendo que o exército vermelho desceria dos céus em discos voadores.

Conforme Sicilier e Labarte (1958, p. 56) "[...], a aparição de discos voadores marca, com efeito, os primeiros sintomas da guerra fria que acometem [...] os dois blocos econômicos e militares mais poderosos do mundo." Os dois autores afirmam que tais eventos habitam com novas cores o imaginário que a $s c i-f i$ fortalece na relação entre ciência e fantasia. Afinal, se a bomba atômica, algo até então impensável em termos de poder de destruição, tornou-se uma realidade, que outros prodígios a ciência não poderia materializar? No campo da sci$f i$, a concretude de uma fantasia científica é uma possibilidade.

Iniciamos, com a contextualização da sci-fi cinematográfica nos anos cinqüenta, por conta das primeiras versões por nós analisadas e por conta da literatura da área que aponta esse período como o de maturidade do gênero no espaço do cinema.

Apesar das divergências quanto ao que o rótulo sci-fi abarca, a questão da ficcionalização da ciência (com maior ou menor grau de contaminação do fantástico e do mítico) centra a discussão nesse tipo de saber, levando a um tipo de desbastamento dos perfis subjetivos das personagens. Daí alguns autores considerarem que a narrativa de sci-fi não se atém aos indivíduos e sim aos eventos e ideias e se encontraria presa a uma perspectiva "pragmática, idealista, apoiada na mística da tecnologia e na crença nas vantagens da aplicação da ordem matemática às coisas humanas." (BAXTER, 1984, p. 15). O enfoque seria nas ideias, e o ser humano não se apresentaria em sua individualidade, pois a personagem principal pode ser a ciência ou uma temática que envolva a tecnociência. A relevância da ciência no enredo levaria a essas considerações. No entanto, esse traço pode ser percebido de outra forma.
Nasci-fi,duasgrandescategoriasparecemcatalisar os acontecimentos: a perda da individualidade e o conhecimento como ameaça. A estas duas categorias, e mais correlata ao conhecimento como ameaça, está o tema fundamental do conhecimento humano poder representar a destruição da própria humanidade: "ao criar, ao inventar, ao renovar, penetramos num universo que não é o nosso, numa meta-realidade fervilhante de perigos e ameaças. Esse universo encontra-se à partida programado para destruir quem nele penetra." (BARREIROS, 1984, p. 34).

Barreiros (1984) é crítico com relação ao cinema de $s c i$ - $f$, pois considera que ele se prende a imagens negativas da ciência, da técnica e do cientista. O mundo sempre está à beira do desastre, assim como a raça humana e, com isso, a imagem projetiva de futuro é negativa, levando a uma visão nostálgica do passado. Assim, Metrópolis, considerada a primeira obra-prima de $s c i-f i$ cinematográfica, com sua estética visual e seus cenários, determinou um "padrão" que se manteve em produções posteriores, quando se propunha a desenhar a metrópole do futuro em perspectivas negativizantes. Porém, é possível perceber um tipo de mudança nas questões abordadas nos filmes de sci-fi ao longo do tempo, destacando-se, sobretudo, os anos cinqüenta, quando "a ciência, como sonho da razão, gera os monstros de Goya" (BARREIROS, 1984, p. 43). O diferente é inimigo, o que para o autor pode ser entendido psicanaliticamente: o outro na verdade é um reflexo de tudo que sentimos, mas recusamos a aceitar. Tal perspectiva já estava presente em Barthes (1987, p. 34), quando ao abordar algumas mitologias, entre os anos de 1956 e 1957, aponta que Marte e os marcianos seriam um nosso reflexo, uma Terra sonhada, idealizada e, sobretudo, uma Terra pequeno-burguesa, em uma construção narrativa que deixa Marte "alinhado pela mais forte das apropriações, a da identidade."

Se, como afirma Barreiros (1984), a sci-fi trabalha com uma inversão de perspectiva, pois ela não trata, propriamente, da influência das pessoas 
no mundo, mas sim da influência do mundo, que se transforma, sobre as pessoas, perguntamo-nos se é válida essa imagem de mundo como ser autônomo que se transforma por si. Se, no centro da sci-fi, está a ciência, no centro desta, está o homem, social e historicamente localizado.

Ao abordar a trajetória do gênero de sci-fi no cinema, Costa (1984) assinala o período de 1977 como um divisor de águas. Nesse ano, o mundo conheceu Guerra nas Estrelas, mas, ao invés de atribuir a esta produção todo mérito de fundamentação do gênero no cinema, Costa afirma que o seu impacto, em termos de mercado e estética narrativa, deve-se a uma situação da qual os filmes de sci-fi são apenas sintoma: uma mudança, no contexto maior de Hollywood, com a emergência de uma nova geração de diretores e produtores, oriundos das escolas de cinema, em uma contrastante diferença com os diretores da considerada época de ouro do cinema (anos de 1940 até 1960).

Nesse ponto, estamos diante de que é considerado um dos grandes diferenciais do gênero: os efeitos especiais que demandam um domínio técnico altamente especializado. Assayas (1984) assinala que não foi Guerra nas Estrelas que trouxe os efeitos especiais para primeiro plano, essa já era uma tendência dos filmes catástrofes. O crítico, em uma visão mais positiva, afirma que os filmes de $s c i-f i$ são vítimas de dois tipos de perspectivas críticas: uma que só vê um tipo de trama arcaica e infantil, herdeira dos quadrinhos, outra que se limita a perceber o espetáculo dos efeitos especiais.

Em termos mais teóricos e menos descritivos, alguns estudos consideram, preponderantemente, o espaço literário, como o trabalho de Broderick (1995) que propõe a sci-fi não como um gênero, mas como um modo de pensar. Partindo da premissa de uma crise epistêmica que marca o início do novo milênio, além de um contexto social de rápidas mudanças e de uma clivagem discursiva entre as duas culturas ${ }^{4}$, ele parece indicar que a $s c i-f i$ pós-moderna deve ser pensada e compreendida considerando tal situação. Para tal, ele se propõe a "mostrar como essas narrativas foram geradas e recebidas (o que implica muito mais do que escrever e ler) no contexto de uma enciclopédia intertextual especializada de tropos e dispositivos, como um arsenal que evolui dentro dessa história específica de crise discursiva." (BRODERICK, 1995, p. xi).

Independentemente de sua lógica de argumentação em torno da $s c i$ - $f i$ não como gênero ${ }^{5}$, mas como modo de pensar esse contexto de crise, e sendo por ele influenciada, trata-se de uma obra de referência para ampliar o escopo das discussões, principalmente quando ele indica o crescimento de estudos acerca da sci $f i$ e atribui tal fato às novas perspectivas dos estudos que abordam a cultural popular e a cultura de massa.

\section{O Gênero como Processo Agregador: As Análises}

$O$ universo de filmes de sci-fi que foram refilmados é enorme. Ao selecionar uma família de filmes, procuramos subsidiar as análises que sustentarão as discussões, sem preocupações com a saturação quantitativa da amostra. Uma questão é importante destacar: os filmes selecionados se autodenominavam remakes. São eles: Família de Planeta dos Macacos (Planet of the Apes, 1968; Planet of the Apes, 2001); Família de Guerra dos Mundos (The War of the Worlds, 1952; War of the Worlds, 2005); Família de Invasores de Corpos (Invasion of the Body Snatches, 1956; Invasion of

\footnotetext{
${ }^{4}$ Aqui identificamos uma referência à obra clássica e polêmica de C. S. Snow, As Duas Culturas, onde o autor discute o abismo entre a cultura das ciências humanas e a das ciências exatas.

${ }^{5}$ Para o desenvolvimento de tal discussão, o autor apresenta uma perspectiva de gênero que não é a nossa.
} 
the Body Snatches, 1978; Body Snachers, 1993; The invasion, 2007); Família de A Máquina do Tempo (The time machine, 1960; The time machine, 2002); Família de A Mosca (The Fly, 1958; The Fly, 1986).

As análises se preocuparam com a relação entre permanência e mudança entre as diferentes produções em cada família e com duas categorias: a perda da individualidade e o conhecimento como ameaça, que emergiram dos estudos sobre esse gênero, sendo que, na última categoria, há a correlata percepção do caráter destrutivo das criações científicas.

A ficha de análise fílmica desenvolvida nesta pesquisa apresenta quatro campos: 1) identificação, onde são descritas as informações técnicas do filme; 2) dimensão textual/narrativa, que explora os aspectos como personagens (no caso cientista e/ou inventor) e referente (objeto em jogo no discurso fílmico; no presente caso, trata-se de todos os elementos relacionados à ciência e tecnologia) e permite o delineamento do filme como texto e narrativa; 3) dimensão contextual, que abarca informações relativas ao contexto de produção do filme em análise; 4) dimensão documental, campo que implica na percepção do filme como documento informacional, cujos elementos constituintes não são coletados do filme, mas oriundos de uma perspectiva interpretativa efetuada sobre as outras duas dimensões, a textual e a contextual. Além desses campos, vimos a necessidade de uma contextualização histórica acerca da ciência no século XX, focalizando as interrelações entre política e ideologia.

A partir das informações coletadas com a ficha de análise, foi possível elaborar um quadro comparativo entre mudança e permanência, com os dois elementos da dimensão textual/narrativa: a personagem, majoritariamente um cientista, e o referente, que, no caso dos filmes analisados, sempre foi a ciência. A análise, em sua totalidade, permitiu construir uma relação entre o movimento de permanência e mudança com os elementos consagradores do gênero e o quadro sócio-histórico e ideológico do contexto da época de produção. Considerando o espaço do artigo, apresentamos somente os elementos de permanência e mudança de cada família de filme. Foram considerados os elementos narrativos personagem e referente e o contexto socioideológico de produção, que foi construído tendo em vista aspectos políticos e científicos de cada período.

\section{Os elementos de permanência e mudança}

\section{Planeta dos Macacos (1968)}

Personagem: Taylor, astronauta capitão da missão de exploração que deveria retornar à Terra. Ele crê na ciência; porém, não crê na humanidade. Em sua opinião, o homem destrói tudo que cria; vê-se como um explorador.

Ciência: É julgada em função das consequências advindas do holocausto nuclear que acabou com a civilização humana. Na sociedade símia, o discurso científico mescla-se ao religioso, em uma postura conservadora, e a raça humana tornou-se degenerada pelos seus próprios atos. O homem como elo perdido é uma heresia científica e vai contra as escrituras. Há posturas diferenciadas, onde cientistas macacos buscam a verdade e o conhecimento isentos dos preconceitos religiosos.

\section{Planeta dos Macacos (2001)}

Personagem: Leo Davidson astronauta/militar; membro da força aérea norte-americana.

Ciência: $\mathrm{O}$ aspecto tecnológico, aliado ao poderio militar, tem maior destaque que o científico na narrativa. Este poder está na base do Estado símio. Há breves referências às pesquisas espaciais desenvolvidas no próprio espaço.

\section{Planeta dos Macacos (1968) $\mathbf{X}$ \\ Planeta dos Macacos (2001)}

Mudança: Da primeira à segunda versão, o cientista perde espaço para o militar. O mesmo ocorre com a questão da ciência: tópicos como o holocausto 
nuclear, o discurso evolucionista e experiências com macacos (ref. 1968) são substituídos pela relação entre poder civil X poder militar e a intervenção a favor da segurança nacional (que, na sociedade dos símios, desequilibraria o Estado democrático a favor de uma ditadura. Ref. Governo Bush) e por uma discussão atenuada sobre direitos dos animais (no caso direito dos humanos, já que eles são animais para os macacos) e sobre desequilíbrio ecológico.

Permanência: $O$ final sem esperança para a humanidade no Planeta Terra. Apesar das diferenças entre as causas da supremacia da civilização dos macacos no futuro, ambas as versões colocam a ação humana como deflagradora deste processo.

\section{Vampiros de Alma (1956)}

Personagem: Bennell é um clínico que pede ajuda a um psiquiatra. Apesar de crer na ciência e na análise dos fatos, ele não nega o caráter inusitado e inexplicável das ocorrências que está testemunhando.

Ciência: O discurso médico-psiquiátrico predomina nas discussões e explicações dos eventos. É cunhado, inclusive, o termo epidemia paranoica, para se tentar compreender o fenômeno coletivo de estranhamento.

\section{Invasores de Corpos (1978)}

Personagem: Bennell é um agente de saúde que procura compreender os eventos estranhos que está presenciando. Ele, também, procura ajuda de um psiquiatra de renome.

Ciência: $O$ discurso médico-psiquiátrico é mais amenizado, pela perspectiva de uma crise dos valores sociais que estariam na base da mudança comportamental dos humanos. A paranóia continua presente, no caso, pela percepção de que há uma conspiração coletiva para alguma finalidade que os protagonistas não conseguem identificar.

\section{Invasores de Corpos (1993)}

Personagem: Marti Malone é uma adolescente rebelde que vive na base militar onde seu pai trabalha. Ela descobre a verdade por trás do comportamento estranho das pessoas. Somente com ajuda do namorado, que é soldado, consegue fugir para avisar os outros sobre a invasão.

Ciência: Uma menção feita diretamente ao campo científico vem da questão da contaminação química da água e solo. Mas ela não sustenta a suspeita da mudança de comportamento das pessoas na base. Nem outra explicação científica surge no lugar.

\section{Invasores (2007)}

Personagem: Carol Bennel é uma psiquiatra com discurso humanístico. Ao lado de seu amigo médico e outro colega bioquímico, descobre a origem do estranho comportamento dos humanos: uma contaminação virótica. Descobre que alguns são imunes, em virtude de doenças adquiridas na infância.

Ciência: $\mathrm{O}$ tratamento dado à questão da invasão é o que mais se aproxima do discurso médico e científico. Inclusive, o número de personagens pesquisadores médicos aumenta: a personagem principal e mais dois pesquisadores da área de saúde empreendem o combate ao organismo alienígena. A invasão é tratada, realmente, como uma pandemia, e com a existência de pessoas resistentes ao microorganismo. Isso é acompanhado pela explicação científica para o processo de contaminação que ocorre por meio da reprogramação do DNA humano pelo organismo alienígena.

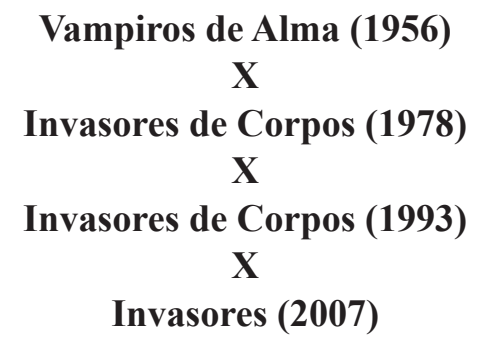

Mudança: A mudança mais significativa em todas as produções reside no final: a primeira, a terceira e a quarta produção indicam uma vitória da raça humana. A segunda versão apresenta o fim do homem no planeta Terra. A terceira versão se distancia com relação à ciência e na composição das personagens. 
Na última versão, pelo fato de a invasão ser tratada como uma pandemia e haver uma explicação científica para o processo de contaminação, há a possibilidade de algumas pessoas serem resistentes à contaminação/substituição, fazendo com que elas não sejam "assimiladas” à nova civilização de pessoas reprogramadas. Isso não estava presente nas demais versões.

Permanência: Todas as produções parecem surgir em períodos nos quais algum tipo de desconforto político ideológico marcava a sociedade americana. Tal fato, aliado ao medo que caracteriza culturalmente essa sociedade, parece marcar estes remakes como metáforas de uma paranoia coletiva em torno da perda da humanidade. A tensão é mantida em todas as produções, por meio do clima de perseguição que parece não deixar saída àqueles que querem resistir. Se os finais são diferenciados, a trajetória das personagens é a mesma: alguns suspeitam do comportamento estranho; outros aderem; outros resistem.

\section{A Máquina do Tempo (1960)}

Personagem: George é um cientista de fins do século XIX. Sua característica principal é a crença na ciência, no seu potencial de desenvolver uma sociedade melhor e mais esclarecida. Ele desenvolve a máquina do tempo, para comprovar sua ideia de que no futuro, devido aos avanços da ciência, a humanidade vive bem melhor.

Ciência: A ciência é um campo ilimitado e potencialmente positivo, apesar da situação da humanidade no futuro. Ela possibilitou o desenvolvimento da máquina do tempo e poderá auxiliar, no futuro, no resgate de uma humanidade perdida.

\section{A Máquina do Tempo (2002)}

Personagem: Alexander é cientista e professor universitário. Ele desenvolve a máquina do tempo, para tentar reverter um problema pessoal: o assassinato da mulher que ama. Suas viagens não têm sucesso e ele começa a se indagar sobre a impossibilidade de, a partir do passado, mudar o futuro.
Ciência: A ciência apresenta-se como um campo de saber que possibilita o desenvolvimento tecnológico-informacional, mas não oferece respostas a determinadas questões, principalmente as existenciais. No entanto, é justamente a perda desse saber acumulado pela humanidade que determina um futuro sombrio para civilização humana.

\section{A Máquina do Tempo (1960) $\mathbf{X}$} A Máquina do Tempo (2002)

Mudança: George e Alexander são movidos por interesses diferenciados. O primeiro procura a comprovação de uma hipótese; o segundo, a solução para uma questão referente ao destino humano e ao tempo. Tal mudança determina, também, uma visão diferenciada de ciência. Na primeira versão, ela é celebrada; na segunda, uma instância importante para se buscar soluções para alguns problemas. Na segunda versão, determinados aspectos do fazer científico são mais destacados, principalmente aquele referente à informação científica em sua dinâmica de produção, circulação e uso. $\mathrm{O}$ evento que determina a destruição de boa parte do planeta, na versão de 1960, é um holocausto nuclear; na versão de 2002, trata-se de uma atividade tecnológica sob a Lua que destrói o equilíbrio entre este satélite e a Terra (construção de colônias subterrâneas).

Permanência: $O$ futuro da humanidade é a degradação. Dois grupos humanos lutam pela sobrevivência: um caçando o outro; os morlock são canibais e os eloi a presa. Em ambas as versões, o cientista decide não retornar ao seu tempo e viver no futuro, tentando tirar os eloi dessa condição, o que só é possível com a destruição completa dos morlock e com a retomada da cultura anterior, o que é possível com a presença do cientista, na primeira versão, e com a presença do Vox Sistem, (um sistema de informação) na segunda versão.

\section{A mosca da cabeça branca (1958)}

Personagem: André Delambre é um cientista obcecado pelo progresso e trabalha no 
desenvolvimento de uma máquina para transporte de massas a distância. Sua visão de ciência é a de um fazer neutro. Acredita no uso da ciência, para um maior conhecimento da natureza e para o progresso do homem.

Ciência: A ciência apresenta uma imagem positiva na perspectiva do cientista, mas a mensagem é do conhecimento como ameaça. Ao final, a mensagem é a de que são necessários sacrifícios para o desenvolvimento científico, e a morte de André deve ser vista dessa forma, pois a ciência funciona para que o homem possa dominar a natureza e resolver os problemas de sua sobrevivência no planeta.

\section{A mosca (1986)}

Personagem: Seth Brundle é gerente de sistemas que projeta um equipamento de teletransporte. Trabalha para uma grande empresa e seu empreendimento é secreto.

Ciência: A ciência emerge a partir da perspectiva da relação com a tecnologia e a indústria de forma mais detalhada. Ela não é positivada nem negativizada, sendo percebida como uma atividade do mesmo nível que o industrial ou comercial, submetida a determinantes econômicos e, sobretudo, ao sigilo das informações que produz.

\section{A mosca da cabeça branca (1958) $\mathrm{X}$ \\ A mosca (1986)}

Mudança: A primeira grande mudança reside na mutação. Na primeira versão, membros do cientista e da mosca são "trocados": o homem passa a ter uma cabeça e uma pata da mosca e esta uma cabeça e um braço humanos. Na segunda versão, há uma fusão em nível genético molecular da mosca com o cientista, resultando em um homem que desenvolve, paulatinamente, uma mutação. Outra transformação é com relação à sexualidade que, na primeira versão, está subsumida na relação familiar. $\mathrm{Na}$ segunda versão, o clima de erotismo é mais explícito. Esta mudança, especificamente, é permitida pela época de cada produção. Na segunda versão, há constantes referências à carne, como alimento, como corpo e como sexo, tanto no discurso, quanto nos objetos e cenas, como a do corpo do cientista que se transforma e deteriora gradativamente. Na primeira versão, o cientista é idealista; na segunda, não se vê exatamente como um cientista, mas um idealizador de um projeto financiado e que não lhe pertence.

Permanência: Um elemento que permanece nas duas narrativas é a experiência mal sucedida, que parece marcar um limite que não deve ser ultrapassado pela ciência. A transformação psíquica também é a mesma: o cientista vai, aos poucos, perdendo a humanidade e a racionalidade. $\mathrm{O}$ final se mantém com a mulher matando o mutante homem-mosca. A relação entre pesquisa e indústria, que está presente na primeira versão, é aprofundada na segunda, ressaltando a questão do segredo.

\section{Guerra dos Mundos (1953)}

Personagem: Clayton Forrester, um astrofísico que traz as explicações plausíveis para todos os eventos, aponta os limites da tecnologia humana no combate a uma força extraterrestre superior. Forrester, também, se vê diante de uma ameaça que consegue explicar, entendendo que somente mais pesquisas ligadas à aplicação bélica podem ajudar o Planeta.

Ciência: Apresenta-se como o discurso da verdade, o que transforma aquele que o domina em uma figura central na trama. Ela, também, está na base do desenvolvimento técnico-militar que pode levar o homem à solução do problema da invasão. Trata-se da ciência física.

\section{Guerra dos Mundos (2005)}

Personagem: Ray Ferrier, homem médio norteamericano, trabalhador, divorciado. Ele, junto a outras centenas de pessoas, constata o poder destruidor dos invasores. Ele domina um saber técnico especializado, advindo de sua experiência profissional, que é suficiente para sua sobrevivência ao longo da jornada.

Ciência: Não há discurso nem prática científica. A ciência não é mencionada, nem mesmo como possível campo a oferecer uma solução ou para tentar explicar o que ocorre. 


\section{Guerra dos Mundos (1953) $\mathrm{X}$}

Guerra dos Mundos (2005)

Mudança: A mudança principal decorre do perfil da personagem principal, que parece determinar o declínio do papel da ciência da primeira à segunda versão. Sem cientista, a ciência, também, perde seu espaço. A primeira versão tem seu foco na ação dos cientistas e das possibilidades armamentistas oriundas das pesquisas nucleares. A segunda versão oferece um panorama diferenciado da invasão, a partir da perspectiva particular do sujeito comum. Sem discutir porque e de onde vieram e como combatê-los, a segunda versão coloca a luta pela sobrevivência em destaque.

Permanência: Apesar do perfil diferenciado das personagens principais e da trajetória de ambos na dinâmica narrativa, a impotência humana diante da invasão é mantida, assim como a solução final: os extraterrestres morrem devido a uma contaminação bacteriológica.

\section{Os Elementos do Gênero entre a Permanência e Mudança}

Tendo em vista a dinâmica de permanência e mudança (centrada no referente e no papel do cientista) e as informações do contexto de produção, podemos indicar que, nas narrativas fílmicas trabalhadas, a permanência estaria mais relacionada ao modo como os elementos do gênero são trabalhados. Ela estaria mais ancorada nesse ponto em que a ciência encontra a ficção. No caso da mudança (novidade), percebemos que ela estaria mais atrelada às mudanças do contexto sociopolíticoideológico de cada produção narrativa. Ela estaria mais ancorada no ponto em que a produção cultural referencia seu contexto de época.

\section{Os Elementos de Permanência: Os Velhos Medos Permanecem}

Os elementos de permanência encontrados nas produções estão mais afinados ao modo como a sci- fi, em geral, trabalha a temática do conhecimento como ameaça e a perda da humanidade, colocando a relação homem e ciência sob perspectiva crítica, denunciado as consequências de suas ações humanas no âmbito de um saber-fazer que deve incluir as questões éticas.

O conhecimento como ameaça e a perda da humanidade: o fim da civilização humana, sua substituição pela dos símios, em virtude da própria ação belicosa do homem (Planeta dos Macacos); a tensão diante de uma invasão alienígena que busca o extermínio da humanidade, atacando de forma indireta, subversiva, criando um clima de paranoia; a perda da humanidade (Invasores de corpos); o futuro da humanidade é a degradação; a civilização como a conhecemos não existe mais. O cientista é o único que tem o potencial de ajudar os sobreviventes do futuro (Máquina do Tempo); a punição do cientista, por meio de sua mutação física e psicológica, com a perda de sua humanidade ( $A$ mosca); a invasão alienígena e a impotência humana diante do inimigo (Guerra dos Mundos).

\section{Mudança: Cada Época Deixa sua Marca}

Os elementos de mudança fazem referência, de forma acentuada, ao contexto de época, o que provocaria a alteração de temáticas ou mesmo de finais de trama.

Em Planeta dos Macacos (1968), tem-se um discurso altamente crítico permeando a fala de um cientista/chefe da missão com relação à ação do homem, às guerras, ao uso de armas nucleares, às experiências com animais. Na versão de 2001, passamos ao militar/homem de ação; à relevância da ação militar e prevenção; à positividade das experiências genéticas com animais.

Em Invasores de corpos, o final de cada produção é significativo: em 1956, o protagonista consegue, avisando as autoridades, por fim à invasão; na versão de 1978, toda a humanidade é "contaminada", não há salvação; na versão de 1993, a vitória da raça 
humana é sombria, anunciando que a invasão pode retornar; finalmente, na última versão, de 2007, a invasão é vencida pela criação de uma vacina. Em cada final, há uma referência a como o alienígena é percebido e como é combatido: de insidioso, em 1956, chega ao início do século XXI com aspecto de bactéria.

Em Máquina do Tempo, o cientista tem propósitos diferentes em cada versão. A versão de 1960 traz um inventor/cientista imbuído de um ideário positivo da ciência e do potencial de aplicabilidade de uma teoria (quarta dimensão), mas, ao mesmo tempo, desiludido com seu tempo, em virtude das guerras. Ele se transforma na única possibilidade de soerguimento da civilização humana, em um futuro devastado pelo holocausto nuclear (motivo razoável de se pensar em 1960). Na segunda versão, de 2002, o objetivo de responder a uma grande questão que derruba suas expectativas (se há ou não possibilidade de alterar os eventos do passado) leva o cientista a uma busca no futuro e a encontrar a civilização humana dividida em duas raças, depois de um grande desastre "ecológicoespacial": a destruição da lua em virtude da ação humana. Ao lado de um sistema informacional, ele consegue reiniciar "um processo civilizatório".

A mosca, de 1958, traz uma mutação física que se assemelha a uma troca dos membros do homem com o da mosca. Na segunda versão, de 1986, há uma fusão, em nível genético, provocando terríveis transformações físicas que são interpretadas como uma doença infecciosa, o que, nos anos de 1980, foi identificado, por críticos, com o HIV. Na segunda versão, há uma mudança na personagem principal, que não é mais o cientista solitário da primeira versão. Trata-se de um cientista inserido em um sistema maior de tecnociência cujo trabalho é vendido a uma indústria e o segredo é indispensável.

Finalmente, em Guerra dos Mundos, a mudança entre as versões é de nível acentuado. Na primeira versão, de 1953, temos um cientista que tudo explica e uma aliança entre ciência-força militar-religião que possibilita um final com tons religiosos. Na segunda versão, de 2005, o cientista desaparece, dando lugar ao homem comum. O discurso científico, também, decresce e o inimigo é mais difuso, sendo identificado, logo na abertura, ao povo do oriente médio, fato mais factível nesse início de século XXI.

A dinâmica de permanência e mudança estabelece uma relação com as duas categorias analisadas (perda da individualidade e conhecimento como ameaça), na medida em que são elas que sofrem, ou não, a transformação. Assim, tendo em vista a perda da individualidade e o conhecimento como ameaça, temos a possibilidade de perceber, nas famílias de filmes analisadas, que, no primeiro caso, há produções nas quais esse tema não se perde nos remakes.

A perda da individualidade está presente no discurso médico-psiquiátrico sobre paranoia, perseguição e medo, e na questão do individualismo, como qualidade positiva inerente ao homem (família de filmes de Invasores de Corpos). Na versão de 1956, a narrativa está no contexto da Guerra Fria e os efeitos de mudança de comportamento, em virtude da invasão alienígena, são atribuídos à paranoia. Em Invasores (2007), emerge o discurso epidemiológico sobre a ação do "vírus" invasor, os dilemas da natureza humana e os caminhos do homem, em termos políticos e sociais.

No caso do conhecimento, como ameaça, vemos como está presente em produções nas quais o fim da civilização humana é causado por desastres provocados pelo próprio desenvolvimento tecnocientífico (primeiras versões de Planeta dos Macacos e Máquina do Tempo). Isso de forma mais clara na primeira versão de O Planeta dos Macacos de 1968 , do que na versão de 2002. O conhecimento, como ameaça, está presente no holocausto nuclear e no desenvolvimento tecnológico que afetou o ambiente, na condição de informação sobre as consequências dessa ameaça que, nos anos de 1960, era nuclear e, no início do século XXI, é ecológica. 


\section{Considerações Pontuais}

No contexto dos remakes analisados, os elementos que se propagam dentro do gênero sofreram algumas variações nas refilmagens, que puderam ser identificadas em relação ao contexto sócio-histórico, principalmente no caso do conhecimento como ameaça. Mas é justamente a capacidade de continuar, como elemento que alimenta o gênero e mudar conforme o contexto de época da produção, que tornou possível construir algumas considerações acerca da dinâmica do gênero em relação às proposições de Bakhtin, percebendo o gênero como órgão de memória, ou seja, como agenciador dos elementos característicos de uma determinada produção ficcional, nos casos estudados.

Tendo em vista as análises efetuadas no conjunto de filmes selecionados, podemos apontar para o fato de que as narrativas ficcionais do gênero de $s c i-f i$ produzidas imageticamente apresentam a ciência como representação de uma visão de mundo. Elas, também, mostram os fatos científicos e os atores envolvidos com a ciência como elementos de uma ordem simbólica social e ideologicamente construída.

O gênero, pautado nessa dinâmica de permanência e mudança, constitui-se, também, como fator preponderante na construção de uma memória da ciência que não se vincula aos discursos acadêmicos, mas, sim, ao espaço do imaginário tecnológico do homem contemporâneo.

As narrativas de sci- $f$ trabalham com a ficcionalização de questões científicas, para referenciar as problemáticas do homem e sua relação racional com o mundo. Em decorrência do aspecto ficcional que tais narrativas apresentam, a força do gênero emerge como elemento adequado, no sentido bakhtiniano, para pensarmos como algumas informações são acionadas nestas narrativas ficcionais.

Relembrando a crise apontada por Broderick (1995), não deixamos de perceber que os filmes aqui analisados parecem assinalar diferentes modos de problematizar questões conflitantes, em termos não somente científicos, mas, sobretudo, políticos e sociais. E, se pensarmos em uma possível influência do contexto de produção, não queremos indicar que seja por meio de uma simples apropriação temática. É possível identificar elementos que são configurações do próprio gênero de sci-fi, no modo como as crises são trabalhadas.

O gênero, conforme apresentamos neste trabalho, compreende a dinâmica dos caracteres inerentes a uma determinada produção cultural, ou seja, no nosso caso, daquilo que diz que uma narrativa é de sci-fi. Tal dinâmica deve, ao mesmo tempo, conter os elementos que renovam o gênero e que garantem sua força aglutinadora, sua estabilidade como horizonte de produção, oferecendo as diretrizes próprias às novas produções que nele são gestados.

Tal consideração acerca do gênero tornouse importante, ao percebermos o imbricamento entre ficção e ciência. A narrativa de sci-fi pode tanto desenhar um tipo de cientista afinado com um imaginário dos anos cinquenta (Guerra dos Mundos, 1952; A mosca, 1958), quanto outro tipo, mais referenciado às questões contemporâneas, quando a atividade científica não é mais percebida como neutra nem como algo diferenciado de qualquer outra atividade (Invasores, 2007). $\mathrm{Ou}$ mesmo, transformar o protagonista em um indivíduo comum (Guerra dos Mundos, 2005) ou um militar ( $O$ planeta dos macacos, 2001), deixando para outros elementos a marca do gênero. As análises da categoria personagem cientistainventor indicaram mudanças e permanências que podem ser explicadas pelo contexto sócio-histórico e que são garantidas pela dinâmica do gênero. À parte as possibilidades e escolhas de determinadas correntes cinematográficas, estúdios, tendências ou estilos de alguns diretores, entendemos que a condição de possibilidade de um protagonismo ou de uma temática em $s c i-f i$ é dada pelas questões que estão presentes no período da produção. 
Entendemos que a memória do gênero, no sentido que é tomado na obra de Bakhtin e conforme foi discutida a partir dos filmes de $s c i$ - $f$, é dotada de uma ação que agencia os elementos de esferas diferenciadas conforme duas grandes perspectivas: a científica e a ficcional. Além disso, ela é constituinte da própria dinâmica de produção das narrativas que retomam elementos simbólicos em diferentes épocas e contextos. A perda da individualidade e o conhecimento, como ameaça, recebem cores diferenciadas nos anos cinquenta e no início do século XXI, mas não deixam de marcar o gênero de $s c i-f i$ como um "termômetro" de discussões sociais do presente. O futuro, principalmente, é projetado em função desses elementos garantidos pelo gênero: as temáticas permanecem, mas as problemáticas são reelaboradas.

\section{Referências}

ASIMOV, I. No mundo da ficção-cientifica. Rio de Janeiro: Francisco Alves, 1984.

ASSAYAS, O. Spfx news (ou a situação do cinema de ficção-científica encarado como sector de vanguarda). Ciclo de cinema de ficção-científica. Lisboa: Fundação Calouste Gulbenkian, 1984.

BAKHTIN, M.Problemas da poética de Dostoiévski. 3. ed. Rio de Janeiro: Forense Universitária, 2005.

BARREIROS, J. M. FC no cinema: a história de uma traição? Ciclo de cinema de ficção-científica. Lisboa: Fundação Calouste Gulbenkian, 1984.

BARTHES, Roland. O prazer do texto. São Paulo: Perspectiva, 1987.

BAXTER, J. A ficção-científica no cinema. Ciclo de cinema de ficção-científica. Lisboa: Fundação Calouste Gulbenkian, 1984.

BAZIN, A. Remade in USA. Cahiers du Cinéma, Paris, n. 11, p. 54-59, Avr. 1952.

BELTON, J. American cinema/American culture. New York: McGraw-Hill, 1994.
BRODERICK, D. Reading by starlight: postmodern science fiction. London: Routledge, 1995.

BURGOYNE, R. A nação do filme. Brasília: UnB, 2002.

CARDOSO, C. F. Ficção-científica, percepção e ontologia: e se o mundo não passasse de algo simulado? História, Ciências, Saúde, Rio de Janeiro, v. 13, p. 17-37, out. 2006.

CLOT, Y. A função psicológica do trabalho. Petrópolis: Vozes, 2006.

COSTA, J. B. F for fiction. Ciclo de cinema de ficção-científica. Lisboa: Fundação Calouste Gulbenkian, 1984.

CUNHA, N. Ficção-científica. Dicionário SESC: a linguagem da cultura. São Paulo: SESC, 2003.

ECO, U. Innovation et repetition: entre esthétique moderne et post-moderne. Réseaux, Paris, v. 12, n. 68, p. 9-26, 1994. Disponível em: <http:enssib. fr/autres-sites/reseaux-cnet/>. Acesso em: 22 fev. 2009.

MARIGNY, J. Relações entre a ciência e o irracional na literatura fantástica e na ficção anglo-saxônicas. In: REEVES, H.; MILNER, M.; GAILLARD, F. Ciência e imaginário. Brasília: Universidade de Brasília, 1994.

MAZDON, L. Introduction. Journal of Romance Studies, New York, v. 4, n. 1, p. 1-11, 2004.

MORSON, G. S.; EMERSON, C. Mikhail Bakhtin: creation of a prosaics. California: Stanford University Press, 1990.

SERCEAU, M.; PROTOPOPOF, D. Le remake et l'adaptation. Paris: Cinemaction, 1989.

SILIER, J.; LABARTHE, A. S. Images de la science-fiction. Paris: Éditions du Cerf, 1958.

STABLEFORD, B. Science fiction before the genre. In: JAMES, E.; MENDLESOHN, F. Science fiction. Cambridge: Cambridge University Press, 2003. p. $15-32$. 
SUVIN, D. On the poetics of science fiction genre. In: ROSE, M. Science fiction: a collection of critical essays. New Jersey: Prentice-Hall, 1976. p. 57-71

. The state of the art in science fiction theory: determining and delimiting the genre. Science Fiction Studies, v. 6, n. 17, 1979. Disponível em: $\quad<$ http://www.depauw.edu/sfs/backissues/17/ suvin17.htm>. Acesso em: 22 fev. 2009. 
